\title{
Asphyxiating Thoracic Dysplasia: clinical and molecular review of 42 families
}

\author{
V Cormier-Daire*, C Huber, J Baujat, R Caumes, H Kayirangwa, M Le Merrer, KH Le Quan Sang, A Munnich \\ From First International Cilia in Development and Disease Scientific Conference (2012) \\ London, UK. 16-18 May 2012
}

Asphyxiating Thoracic Dysplasia (ATD) ((MIM 208500, MIM 6112633, MIM 613091, MIM 61819, MIM614376) belongs to the short rib polydactyly group and is characterized by a long and narrow thorax, short long bones and trident acetabular roof. Polydactyly, retinal degeneration, cystic renal and liver diseases have been occasionally reported. Today, mutations in IFT80 (MIM 611177), DYNC2H1 (MIM 603297), TCC21B (MIM 612014) and WDR19 (MIM 608151) genes have been reported in ATD. Through a national grant (PHRC, AOM 06031), we have collected 55 ATD cases including 29 fetuses issued from 42 families who benefit the combined approach of deep phenotyping and molecular screening of IFT80 and DYNC2H1. The series included 26 alive cases ranging in age from 6 months to 36 years. Respiratory treatment was needed in $46 \%$, including positive pression respiration, and invasive or non-invasive ventilation. Cystic renal and liver diseases occur in $16 \%$ of cases; whereas retinal degeneration was present in $40 \%$ cases aged more than 2 years $(6 / 15)$. The molecular screening allowed us to detect DYNC2H1 mutations in 63\% and IFT80 mutations in $6 \%$. In 6 cases, only one heterozygote mutation in either IFT80 or $D Y N C 2 H 1$ was identified. Finally, the two genes were excluded in $31 \%$ cases. These preliminary results emphasize that $D Y N C 2 H 1$ is the major gene responsible for ATD. The presence of only one mutation ( $27 \%$ of mutated cases) may suggest a digenic diallelic inheritance. Ongoing studies will hopefully lead to the identification of other disease genes.

Published: 16 November 2012

* Correspondence: valerie.cormier-daire@inserm.fr

Département de Génétique, INSERM U781, Hôpital Necker Enfants Malades, France

C Biomed Central

@ 2012 Cormier-Daire et al; licensee BioMed Central Ltd. This is an Open Access article distributed under the terms of the Creative Commons Attribution License (http://creativecommons.org/licenses/by/2.0), which permits unrestricted use, distribution, and reproduction in any medium, provided the original work is properly cited.
doi:10.1186/2046-2530-1-S1-O4

Cite this article as: Cormier-Daire et al:: Asphyxiating Thoracic Dysplasia: clinical and molecular review of 42 families. Cilia 2012 1(Suppl 1):O4.

Submit your next manuscript to BioMed Central and take full advantage of:

- Convenient online submission

- Thorough peer review

- No space constraints or color figure charges

- Immediate publication on acceptance

- Inclusion in PubMed, CAS, Scopus and Google Scholar

- Research which is freely available for redistribution 